2. Гримм Д. Д. Лекции по догме римского права. Москва, 2003. $304 \mathrm{c}$.

3. Киприан Карфагенский. Письмо к Помпею против письма Стефана о крещении еретиков: Сборник писем. Москва, 2008. 340 с.

4. Климент Александрийский. Строматы. Санкт-Петербург, 2003. $302 \mathrm{c}$.

5. Никодим Милаш. Православное церковное право. Санкт-Петербург, 1897. 400 с.

6. Никодим Святогорец. Пидалион: в 4 т. Т. 3. Екатеринбург, 2019. $260 \mathrm{c}$.

7. Никодим Святогорец. Пидалион: в 4 т. Т. 2. Екатеринбург. 2019. $270 \mathrm{c}$.

8. Ухтомский А. А. Православная диаспора: проблема формирования канонического статуса. Церковь и время. 2009. № 3 (48). Москва, 158 с.

9. Цыпин В., Каноническое право. Москва, 2009. 720 с.

10. Энгельман И. Е. О давности по русскому гражданскому праву: историко-догматическое исследование. URL: http://civil.consultant.ru/ elib/books/2/page_15.html\#ftn_70 (дата обращения: 25.02.2021)

DOI https://doi.org/10.30525/978-9934-26-040-7-15

\title{
СУЧАСНИЙ ТЕОРЕТИКО-ПРАВОВИЙ ПІДХІД ДО РОЗУМІННЯ ЗАХИСТУ ПРАВ ЛЮДИНИ
}

\author{
Чепульченко Т. 0. \\ кандидат юридичних наук,
} дочент кафедри публічного права факультету соиіології і права Національного технічного університету України «Київський політехнічний інститут імені Ігоря Сікорського» м. Київ, Украӥна

Проблема захисту прав людини займає гідне місце у науковій правовій доктрині. Втім, незважаючи на значні здобутки вчених у даній сфері, а також на існування системи актів національного законодавства 3 питань захисту прав людини, комплексу актів міжнародного права, згоду на обов’язковість яких надано Верховною Радою України, 
чисельні питання потребують вирішення й удосконалення. Зокрема, важливою та актуальною є розробка ефективних механізмів і юридичних засобів забезпечення і захисту прав і свобод людини, моніторинг проблем взаємодії людини та держави, відповідальності останньої перед людиною тощо.

3 огляду на необхідним є розуміння поняття невід'ємних прав людини та рівень їх відображення в нормативно-правових актах.

Зміст природних прав змінювався від епохи до епохи і для кожної 3 них були характерні свої специфічні стандарти правової поведінки, свої охоронювані законом цінності. Виникнення багатьох соціальних, політичних, громадянських прав конкретної особи відбувається не в момент народження, а в момент їх закріплення [1, с. 140]. Це, зокрема, вказує на потребу належного формулювання та закріплення основних прав людини, які сьогодні є міжнародними стандартами, у законодавстві України. Саме у такий спосіб можна спостерігати, як природне право трансформується у право позитивне, як дух права набуває своєї форми у вигляді законодавства.

У п. 3 ст. 1 Статуту ООН проголошено, що «одним із завдань Організації Об'єднаних Націй є здійснення спільної діяльності держав - членів Організації, спрямованої на те, щоб права людини дотримувалися і поважалися усіма, незалежно від раси, статі, мови та релігії. Відповідно до цього положення Україна як один із засновників $\mathrm{OOH} \mathrm{взяла} \mathrm{на} \mathrm{себе} \mathrm{зобов'язання} \mathrm{діяти} \mathrm{самостійно} \mathrm{або} \mathrm{разом} \mathrm{з} \mathrm{іншими}$ державами для досягнення загальної поваги до прав людини та їх реалізації» [2, с. 23]. Відповідно, у Декларації про державний суверенітет України від 16 липня 1990 року закріплено перевагу загальнолюдських цінностей над класовими, пріоритет загальновизнаних норм міжнародного права перед нормами внутрішньодержавного права [3].

Власне, міжнародні стандарти прав людини своїми витоками мають права природні, тобто ті, які людина має від народження, не залежно від державно-владного втручання, і тому вони є невідчужуваними. Конституція нашої держави відображає даний міжнародний стандарт у сфері захисту прав людини, а саме, у ст. 21 Конституції України зазначається, що «права і свободи людини є невідчужуваними та непорушними» [4].

У правовій науці обгрунтовується позиція, відповідно до якої «інститут прав і свобод людини і громадянина, що міститься в Конституції, базується на поєднанні природно-правових і позитивістських підходів. Природне право як основа норм і принципів загальновизнаних прав людини включає ідеали свободи, справедливості, рівності усіх перед законом, визнання народу як єдиного джерела 66 
влади. «Застосовуючи природно-правовий підхід, пише А. Саїдов, Конституція визнає автономію особистості, іiі право на невтручання в сферу окресленої правом свободи особистості, ставить заслін всевладдю держави $\mathrm{i}$ його зазіханням на розвиток свободи та індивідуальності особи» [5, с. 15].

Із прийняттям Конституції України 28 червня 1996 р., яка встановила новий конституційний статус людини і громадянина на основі сучасної ліберальної концепції прав людини у відповідності iз визнаними світовим співтовариством стандартами в галузі прав людини, людина визнається суб'єктом прав і свобод людини i громадянина.

Із сучасної концепції прав людини випливають також інші надзвичайно важливі положення Основного Закону, які не були приманні конституціям радянського режиму: про невідчужуваність i непорушність прав і свобод людини (ст. 21), про те, що конституційні права і свободи не можуть бути скасовані ( ст. 22), про їх рівність для всіх громадян (ст. 24). Це означає, що держава не може позбавити людей їх іманентних властивостей, які б мотиви вона при цьому не висувала. Щонайбільше, державі дозволяється обмежити певні прав для окремих людей чи їх об'єднань і лише з метою забезпечення національної безпеки, запобігання злочинам, охорони здоров'я, захисту прав інших людей та за наявності умов, визначених Конституцією і законами. Будь-які обмеження прав за ознаками раси, кольору шкіри, політичних, релігійних та інших переконань, статі, етнічного та соціального походження, майнового стану, місця проживання, за мовними або іншими ознаками не допускаються (ст. 24).

Отже, «втілюється у життя нова концепція взаємовідносин української держави і особи з пріоритетом останньої, адже категорія прав людини діє виключно у стосунках між людиною і владою. Права людини - це межі влади. Вони визначають ту сферу життєдіяльності людини, в яку влада (держава) не може втручатись і ті обов'язки, які має держава щодо людини» [6, с. 260-261]. Стосунки між людиною і владою передбачають особливий характер: «...Концепція прав людини грунтується на трьох положеннях: по-перше, кожна влада обмежена; по-друге, кожна людина має свій автономний світ, втручатися в який не може жодна сила; по-третє, кожна людина захищаючи свої права, може висунути претензії до держави» [7, с. 230].

Такий концептуальний підхід до розуміння сутності прав людини не міг не вплинути й на розуміння їх захисту. Як наголошують вчені, «багато визначень прав людини сформульовано із використанням терміну «захист»: захист від посягання, забезпечення державним 
захистом, право на захист інтересів та ін. Термін «захист прав людини», незважаючи на своє широке використання у законодавстві та юридичній літературі, не забезпечений єдиним науковим тлумаченням. Як правило, його дослідження супроводжується зіставленням двох категорій: «захист прав людини» та «охорона прав людини», а найчастіше - їх розмежуванням. Відзначається, що охороняються права i свободи перманентно, а захищаються тільки тоді, коли порушуються або оспорюються. Захист прав людини характеризується рядом ознак: це певна діяльність по застосуванню тих чи інших законних способів і засобів захисту, що здійснюються як державними органами, так i громадськими об'єднаннями або людиною самостійно; спрямована на усунення порушення права, підтвердження або відновлення оскарженого або порушеного права; є примусовою за своїм характером, що має на увазі не тільки саме примус, а й можливість його застосування». 3 огляду на це, захист прав людини визначається як «застосування в установленому законом порядку компетентними органами або самостійно самою зацікавленою особою примусових заходів впливу щодо зобов'язаної особи з метою підтвердження або відновлення оскарженого або порушеного права» [8, с. 149].

Саме тому постановка питання охорони та захисту прав людини передбачає взаємовідносини у площині «особа - держава», де на кожному учасникові правовідносин лежить певний обсяг прав чи обов'язків.

Зокрема, Н. Оніщенко визначає поняття прав людини саме у розрізі передусім обов'язків, а не прав. Так, вчена пише, що «права людини це формально визначені у відповідний спосіб зафіксовані обов'язки держави» [9, с. 14].

Українська правники, також аналізуючи саме такий аспект, наголошують на тому, що «у особи по відношенню до держави $є$ права, а на державі лежать обов'язки по відношенню до особи, громадянина. Закріплюючи в праві міру свободи, держава в цих же межах самообмежується у власних рішеннях і діях, бере на себе зобов'язання забезпечити справедливість у відносинах з кожною особою. 3 огляду на це зазначається що права і свободи людини - це їі соціальні можливості в різних сферах життя: економічній, політичній, соціальній, культурній, особистій. Їх обсяг свідчить про рівень демократизму громадянського суспільства» [9, с. 12-13].

Отже, узагальнюючи все вищевикладене можна констатувати, що міжнародні стандарти прав людини своїми витоками мають права природні, тобто ті, які людина має від народження, не залежно від державно-владного втручання, i тому вони $\epsilon$ невідчужуваними i 68 
підлягають особливому захисту. Поняття «захист прав людини» ми визначаємо як діяльність компетентних державних органів або інших суб'єктів права в межах їх повноважень, яка передбачає усунення порушення прав особи чи їх відновлення у законний спосіб.

\section{Література:}

1. Макаренко Л. О. Правова культура: теоретико-методологічні основи дослідження : монографія. Київ : Парлам. вид-во, 2019. 576 с.

2. Ісакович С. Механізм діяльності ООН щодо захисту прав людини // Украӥнський часопис прав людини. 1994. № 1. С. 19-29.

3. Декларація про державний суверенітет України 1990 р. // Офіиійний веб-сайт Верховної Ради Украйни. URL: https://zakon.rada.gov.ua/laws/show/55-12\#Text

4. Конституція України 1996 р. // Офіиійний веб-сайт Верховної Ради України: URL:https://zakon.rada.gov.ua/laws/show/254\%D0\%BA/96$\% \mathrm{D} 0 \% \mathrm{~B} 2 \% \mathrm{D} 1 \% 80 \#$ Text

5. Саидов А. Х. Общепризнанные права человека : учеб. пособие / под ред. И. И. Лукашука. Москва : МЗ «Пресс», 2002. 268 с.

6. Чепульченко Т. О. Концепція прав людини: доктринальні підходи // Альманах права. Роль правової доктрини у забезпеченні прав людини. Вип. 11. Київ : Інститут держави і права ім. В. М. Корецького НАН України, 2020. С. 258-264.

7. Львова О. Л. Людина як найвища соціальна цінність (через призму християнського світогляду та реальності) // Альманах права: Правовий світогляд: людина і право. Вип. 5. Київ : Ін-т держави і права ім. В. М. Корецького НАН України, 2014. С. 227-233.

8. Права человека : учеб. пособие / С. А. Балашенко [и др.]; науч. ред.: С. А. Балашенко, Е. А. Дейкало. Минск : Юнипак, 2015. 200 с.

9. Оніщенко Н. М. Правова доктрина, юридична наука та захист прав людини (коефіцієнт корисної дії) // Альманах права. Роль правової доктрини у забезпеченні прав людини. Вип. 11. Київ : Ін-т держави і права ім. В. М. Корецького НАН України, 2020. С. 11-14. 